
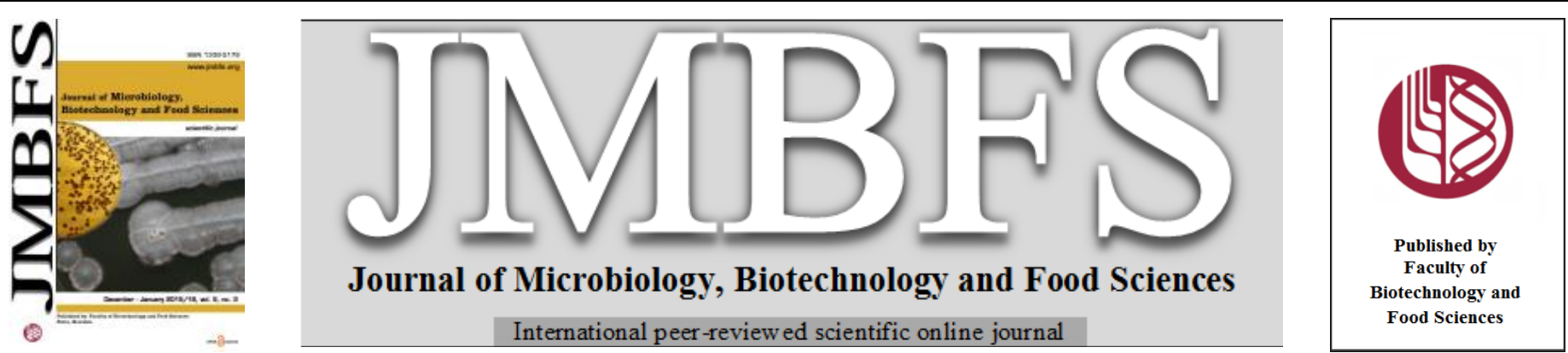

\title{
GC-MS ANALYSIS OF CHANGE IN FATTY ACID COMPOSITION OF HALOBACTERIUM BACILLUS LICHENIFORMIS HSW-16 UNDER VARYING SALINITY CONDITION
}

\author{
Rajnish Prakash Singh ${ }^{1}$, Somesh Mishra ${ }^{2}$, Smita Raghuvanshi ${ }^{2}$, Prabhat Nath Jha ${ }^{1}$
}

Address(es): Rajnish Prakash Singh,

${ }^{1}$ Dept. of Biological Sciences, Birla Institute of Technology and Science (BITS), Pilani-333031, Rajasthan, India.

${ }^{2}$ Dept. of Chemical Engineering, Birla Institute of Technology and Science (BITS), Pilani-333031, Rajasthan, India.

*Corresponding author: manasrajnish2008@gmail.com

doi: $10.15414 / j m b f s .2015 / 16.5 .3 .290-292$

\section{ARTICLE INFO}

Received 22. 6. 2015

Revised 24. 7. 2015

Accepted 17. 8. 2015

Published 1. 12. 2015

Regular article

OPEN $\partial_{\text {ACCESS }}$

\section{ABSTRACT}

The salt concentration have a pronounced effect on fatty acid composition, therefore the adaption of fatty acid composition of a halophilic bacterium Bacillus licheniformis HSW-16, grown at different concentration of $\mathrm{NaCl}(0 \mathrm{mM}, 150 \mathrm{mM}, 175 \mathrm{mM}, 200 \mathrm{mM})$ was studied. The common fatty acid observed at various salt concentration were tetratriacontane, triacontane, tetracosane and pentacosane etc..As the salinity increases from $150 \mathrm{mM}$ to $200 \mathrm{mM}$, the bacterium started to accumulating the long chain alkanes and fatty alcohol, suggesting the adaption of bacterium through accumulation varying fatty acids for counteracting the increased salinity and maintaining its osmotic balance in the changing environment.

Keywords: Bacillus, fatty acid, Halobacterium, salinity stress, Salt lake

\section{INTRODUCTION}

Halophilic organism is able to survive under hypersaline and alkaline conditions. The natural niche for these microorganismsis saline soil, salt lake, soda lake etc. (Oren, 2002). However salt tolerant bacteria has been divided into two groups, one euryhaline: can be able to grow without salt, and stenohaline: $\mathrm{NaCl}$ compulsory for growth and survival (Vreeland, 1987). To cope with changing environmental stresses, these microorganisms accumulate specialized molecules and complexed physiological mechanism. As the salinity increases it imposed the physiological drought stress conditions on a living microorganism that change the osmotic pressure also. Therefore, to protect the cells under these adverse environmental conditions, creation of a hydrophobic membrane layer would be more advantageous. Previous study suggested that under changing environment, the total unsaturated fatty acid content decreases when the osmolality of the growth medium is increased Miller KJ, (1986). The salinity and alkalinity of the soil is increasing day by day because of the extensive use of chemical fertilizer, pesticides etc. for increasing the agricultural productivity and yield.Also, the growth of crop and its productivity is affected by increased salinity therefore, utilization of haloalkalophilic bacterium for reducing the effect of salinity and alkalinity has drawn considerable attention to promote plant growth (Mishra $\boldsymbol{e t}$ al., 2015). The present study aimed to study the fatty acid analysis of a halophilic bacterium Bacillus licheniformisHSW-16 to a wide range of salt stress conditions.

\section{MATERIAL AND METHODS}

\section{Bacterial strain and culture condition}

A halotolerant bacterium Bacillus licheniformis HSW-16 was isolated from the hypersaline lake water of Sambhar lake. Previous study hasreported that thesalinity of lake is $7 \%(\mathrm{w} / \mathrm{v})$ with salt concentration in the range of $12 \%$ to $30 \%$ $(w / v)$. The sulphates, carbonates, bicarbonates, chlorides, sodium and smaller amounts of potassium salts are the major contributor to the salinity (Joshi and Seth 2008). Isolated strain was capable to grow in presence of $\mathrm{NaCl}$ up to concentration of 2 to $11 \%(\mathrm{w} / \mathrm{v})$. To studying the change in fatty acid composition of strain HSW-16, it was cultured in DF medium supplemented with salt concentration $(0 \mathrm{mM}, 150 \mathrm{mM}, 175 \mathrm{mM}, 200 \mathrm{mM})$.Composition of DF medium was as follows (per litre): $\mathrm{KH}_{2} \mathrm{PO}_{4} 4.0 \mathrm{~g}, \mathrm{Na}_{2} \mathrm{HPO}_{4} 6.0 \mathrm{~g}, \mathrm{MgSO}_{4} .7 \mathrm{H}_{2} \mathrm{O}$ $0.2 \mathrm{~g}$, glucose $2.0 \mathrm{~g}$, gluconic acid $2.0 \mathrm{~g}$, citric acid $2.0 \mathrm{~g}$, Trace elements: $\mathrm{FeSO}_{4} .7 \mathrm{H}_{2} \mathrm{O} 1 \mathrm{mg}, \mathrm{H}_{3} \mathrm{BO}_{3} 10 \mu \mathrm{g}, \mathrm{MnSO}_{4} \cdot \mathrm{H}_{2} \mathrm{O} 11.19 \mu \mathrm{g}, \mathrm{ZnSO}_{4} .7 \mathrm{H}_{2} \mathrm{O} 124.6 \mu \mathrm{g}$, $\mathrm{CuSO}_{4} .5 \mathrm{H}_{2} \mathrm{O} 78.22 \mu \mathrm{g}, \mathrm{MoO}_{3} 10 \mu \mathrm{g}$, pH 7.2 (Dworkin and Foster, 1958).

\section{Lipid extraction}

The bacterial strain HSW-16 was grown in DF medium supplemented with different salt $(\mathrm{NaCl})$ concentration from $150 \mathrm{mM}$ to $200 \mathrm{mM}$ and incubated for $24 \mathrm{~h}$ in a rotator shaker at $30{ }^{\circ} \mathrm{C}$. After the incubation period culture was centrifuged at $10,000 \mathrm{~g}$ for $20 \mathrm{~min}$ at $4{ }^{\circ} \mathrm{C}$. After centrifugation, the supernatant was discarded and cell pellet was retained for fatty acid profiling. The obtained cell pallet was suspended in sonicated buffer containing Tris- $\mathrm{HCl}(50 \mathrm{mM}, \mathrm{pH}$ 7.6), dithithretiol (1.1 M), 1 mMphenylmethylsulfonyl fluoride (PMSF) and lysozyme $(0.2 \%)$ and sonication was carried out to obtain the cell lysate. The cellular lipids were extracted in the solvent system, chloroform and methanol in the ratio of 2:1. The obtained cell lysate was diluted ten times with the solvent system and kept on a shaker at $160 \mathrm{rpm}$ for $3 \mathrm{~h}$ to separate the phases. The lower organic phase was concentrated on rotary evaporator and re-dissolved in toluene and converted into fatty acid methyl ester (FAME) by transesterification reaction as described in preceding section.

\section{Transesterification and FAME analysis}

Transesterification reaction was carried out by as per the method of chriestie, (2003). The extracted cellular fatty acids, dissolved in toluene $(5 \mathrm{~mL})$, were subjected to base catalyzed transesterification reaction. One molar $(1 \mathrm{M}), 100 \mathrm{ml}$ stock solution of sodium methoxide was prepared by adding $2.3 \mathrm{~g}$ of sodium metal in methanol. In a $250 \mathrm{ml}$ conical flask, sodium methoxide and methanol solution was taken in the ratio 1:2 and $2 \mathrm{ml}$ of extracted fatty acids dissolved in toluene was added to it. The flask was sealed with a cotton plug to prevent from any contamination and kept in the oven at $50{ }^{\circ} \mathrm{C}$ for $2 \mathrm{~h}$. After $2 \mathrm{~h}$, the glacial acetic acid of $0.1 \mathrm{~mL}$ was added followed by $5 \mathrm{~mL}$ distilled water. The resulting esters were extracted in $10 \mathrm{ml}$ of hexane analytical grade. The hexane layer was dried over anhydrous $\mathrm{Na}_{2} \mathrm{SO}_{4}$ to remove the trace of water. The hexane phase was concentratedon a rotary evaporator. The final concentrated hexane phase rich in esters were profiled using GC-MS (Shimadzu QP-2010 Plus).

Fatty acid analysis by gas chromatography (GC)

The profiling of resultant FAME samples $(1 \mu \mathrm{L})$ was carried out using gas chromatography-mass spectroscopy (GC-MS) (Shimadzu QP-2010 Plus) equipped with a split/splitless injector and capillary column DB-5 MS $(0.25 \mu \mathrm{m}$ film thickness, $0.25 \mathrm{~mm}$ i.d., $30 \mathrm{~m}$ length). The conditions applied for GC analysis were: splitless mode, initial oven temperature $50{ }^{\circ} \mathrm{C}$ which was held for $2 \mathrm{~min}$, injector temperature $250{ }^{\circ} \mathrm{C}$ and detector temperature $230{ }^{\circ} \mathrm{C}$. The 
temperature was increased from $50^{\circ} \mathrm{C}$ to $250^{\circ} \mathrm{C}$ at a rate of $10^{\circ} \mathrm{C}$ per min and was held for $3 \mathrm{~min}$ on reaching $250{ }^{\circ} \mathrm{C}$. The temperature was further increased from $250{ }^{\circ} \mathrm{C}$ to $280{ }^{\circ} \mathrm{C}$ at a rate of $15{ }^{\circ} \mathrm{C}$ per min and was held for 5 min on reaching $280^{\circ} \mathrm{C}$. The helium of ultra-high purity was utilized as carrier gas (head pressure was $72.5 \mathrm{kPa}$ and flow rate was maintained as $1.21 \mathrm{ml} \mathrm{min}^{-1}$ ). The conditions applied for MS analysis were: scan mode, start time $4.00 \mathrm{~min}$, end time 31.99 min, scan speed 1250 , event time 0.5 second, start $\mathrm{m} / \mathrm{z} 40.00$ and end $\mathrm{m} / \mathrm{z}$ 650.00. Data was compared with the inbuilt standard mass spectra library system (NIST-05 and Wiley-8) of GC-MS.

\section{RESULTS AND DISCUSSION}

The proficiency of HSW-16 in the environment of varying salt concentration ( $150 \mathrm{mM}$ to $200 \mathrm{mM}$ ) was studied by observing the composition of cellular extract. The composition of cellular extract was analyzed using GC-MS analysis at respective salt concentration. A control was also placed with $0 \mathrm{mM}$ salt concentration to investigate the change in fatty acid composition. The obtained GC-MS profile of cellular extract at different salt composition were comprised of hydrocarbons, fatty alcohols and fatty acids with carbon chain length varying in range of $\mathrm{C}_{13}-\mathrm{C}_{44}$. At $0 \mathrm{mM}$ salt concentration (Table 1.), the composition of extract was mainly hydrocarbons with n-tetracosane (6.91\%), n-tetracontane $(9.26 \%)$, hexatriacontane $(11.16 \%)$, pentacosane $(10.72 \%)$, n-tetratriacontane (9.34\%), n-tetratetracontane (7.34\%). The GC-MS analysis of extract at $0 \mathrm{mM}$ salt concentration also showed the presence of fatty acids like tetradecanoic acid $(0.47 \%)$, octadec-9-enoic acid $(0.90 \%)$, and pentadecanoic acid $(2.8 \%)$. As the salt concentration increases from $0 \mathrm{mM}$ to $150 \mathrm{mM}$ (Table 2.), the extract composition changes with increase in concentration of long chain alkanes like hexatriacontane $(11.16 \%)$, pentacosane $(12.56 \%)$, n-tetratriacontane $(12.15 \%)$, ntetratetracontane $(10.25 \%)$. The cell extract (Table 2.) also shows the presence of fatty alcohols like 1-heptadecanol $(0.07 \%)$, 1-nonadecanol $(0.13 \%)$, 1tetracosanol $(0.14 \%)$. At salt concentration of $175 \mathrm{mM}$ (Table 3.), the composition of cell extract was mainly hydrocarbons like n-tetracosane $(3.08 \%)$, n-tetracontane $(6.20 \%)$, hexatriacontane $(11.20 \%)$, pentacosane $(10.85 \%)$, ntriacontane $(10.01 \%)$, n-tetratriacontane $(6.88 \%)$. Similar composition of cell extract was observed at salt concentration of $200 \mathrm{mM}$ (Table 4.) having hydrocarbon like n-tetracosane $(6.54 \%)$, n-tetracontane $(9.14 \%)$, hexatriacontane $(11.02 \%)$, pentacosane $(10.69 \%)$, n-tetratetracontane $(9.65 \%)$, n-tetratriacontane (7.56\%). At $200 \mathrm{mM}$ salt concentration, fatty alcohols like 1 -heneicosanol $(0.97$ $\%)$, 1-heptadecanol $(0.78 \%)$, 1-tetracosanol $(0.51 \%)$ were also present in the intracellular cell extract. Thus, the GC-MS analysis of cellular extract at varying salt concentration confirmed the presence of long chain hydrocarbon, fatty acid and fatty alcohol. The analysis also shows that as the concentration of the salt increases in the cellular vicinity, the intracellular composition of the cell changes. The two strategies implemented by prokaryotes for survival in osmotic stress is 1 : 'salt in cytoplasm' approach, which requires extensive structural modifications, is restricted mainly to members of the Halobacteriaceae, 2: accumulation of a restricted range of compatible solutes (Present work). In present work, in order to retort the osmotic stress, cell starts accumulating long chain alkanes and fatty alcohol which helps in maintaining the cellular membrane as iso-osmotic with changing salt concentration and crucial for bacterial cell survival. The bacterial species are capable of synthesize fatty alcohols and hydrocarbons intracellular as well extracellular having chain length ranging from $\mathrm{C}_{9}-\mathrm{C}_{20}$. The present study confirmed that the assimilation of different compounds of different composition, nature in response to changing environment of salinity was necessary for bacterium cell survival.

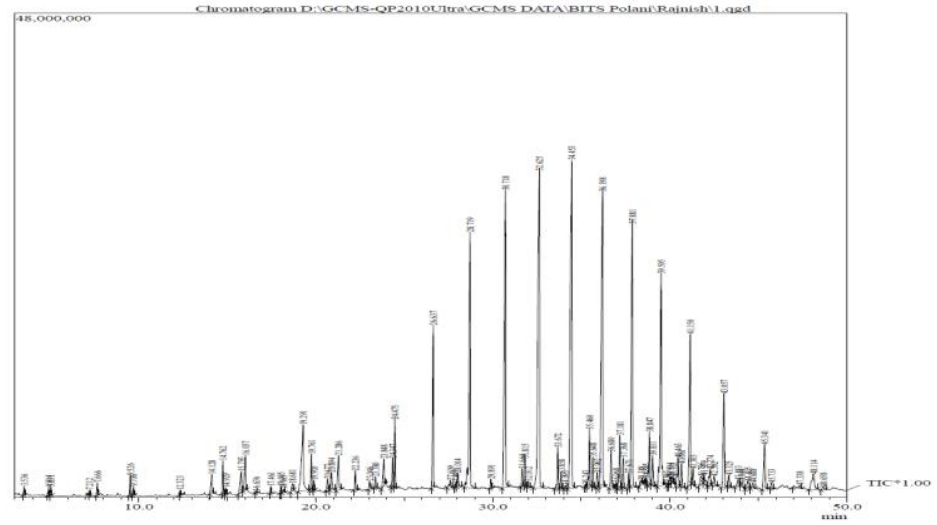

Figure 1 a) GC-MC chromatogram of $\mathrm{HSW}-16$ at $0 \mathrm{mM} \mathrm{NaCl}$

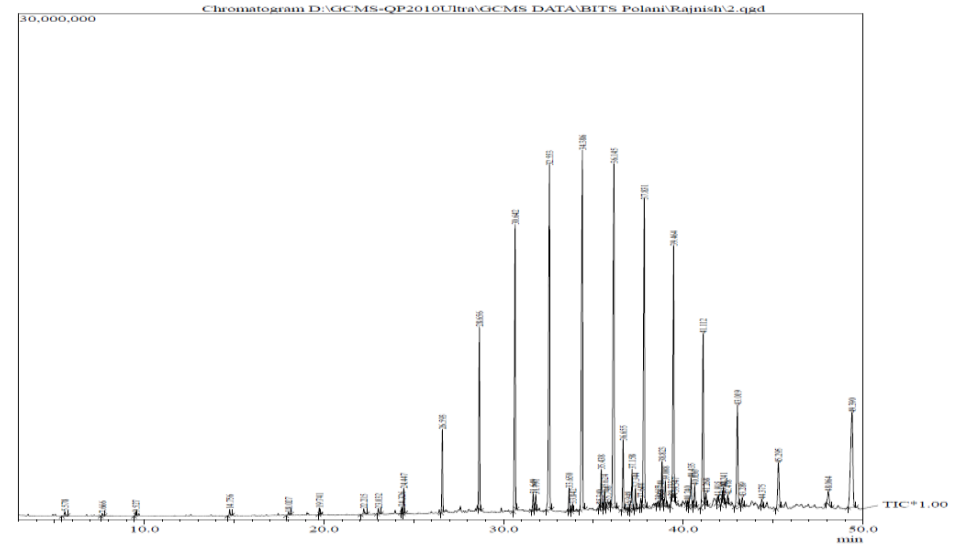

Figure 1 b) GC-MC chromatogram of HSW-16 at $150 \mathrm{mM} \mathrm{NaCl}$

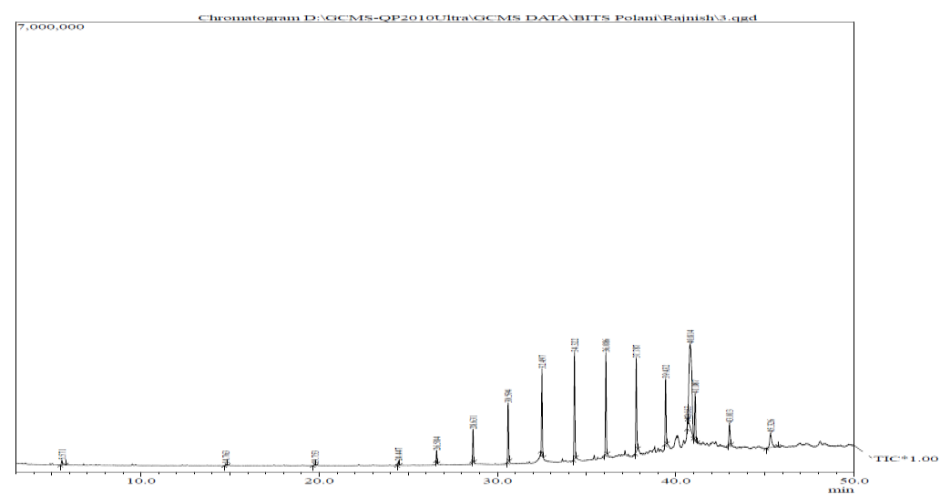

Figure 1 c) GC-MC chromatogram of $\mathrm{HSW}-16$ at $175 \mathrm{mM} \mathrm{NaCl}$

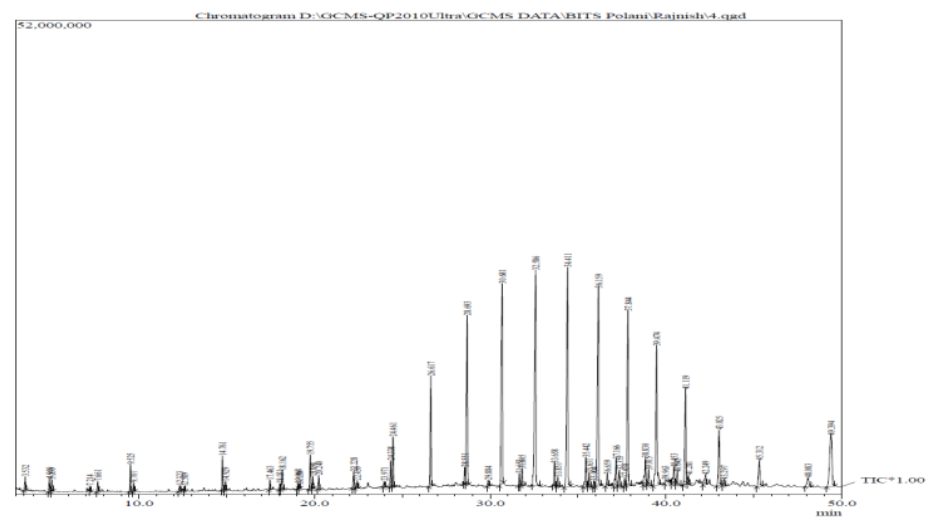

Figure 1 d) GC-MC chromatogram of HSW-16 at $200 \mathrm{mM} \mathrm{NaCl}$ 
Table 1 GC-MS analysis on HSW-16 at 0mM salt concentration

\begin{tabular}{|c|c|c|c|c|c|c|}
\hline S.No. & Run Time & Formula & Compound & $\%$ Area & $\begin{array}{c}\text { Relative } \\
\text { Molecular } \\
\text { mass }\end{array}$ & $\begin{array}{c}\text { Match } \\
\text { quality } \\
\%\end{array}$ \\
\hline 1. & 3.536 & $\mathrm{C}_{13} \mathrm{H}_{28}$ & Tridecane & 0.12 & 184 & 96 \\
\hline 2. & 4.914 & $\mathrm{C}_{14} \mathrm{H}_{28}$ & Tetradecene-1 & 0.12 & 196 & 96 \\
\hline 3. & 14.128 & $\mathrm{C}_{14} \mathrm{H}_{28} \mathrm{O}_{2}$ & Tetradecanoic acid & 0.47 & 208 & 96 \\
\hline 4. & 16.037 & $\mathrm{C}_{18} \mathrm{H}_{34} \mathrm{O}_{2}$ & Octadec-9-enoic acid & 0.90 & 282 & 85 \\
\hline 6. & 19.291 & $\mathrm{C}_{15} \mathrm{H}_{30} \mathrm{O}_{2}$ & Pentadecanoic acid & 2.84 & 242 & 93 \\
\hline 7. & 26.637 & $\mathrm{C}_{30} \mathrm{H}_{62}$ & N-Triacontane & 3.23 & 422 & 96 \\
\hline 8. & 28.719 & $\mathrm{C}_{24} \mathrm{H}_{50}$ & n-Tetracosane & 6.91 & 338 & 96 \\
\hline 9. & 30.718 & $\mathrm{C}_{40} \mathrm{H}_{82}$ & N-Tetracontane & 9.26 & 562 & 95 \\
\hline 10. & 32.625 & $\mathrm{C}_{36} \mathrm{H}_{74}$ & Hexatriacontane & 11.16 & 506 & 95 \\
\hline 11. & 34.453 & $\mathrm{C}_{25} \mathrm{H}_{52}$ & Pentacosane & 10.72 & 352 & 95 \\
\hline 12. & 36.198 & $\mathrm{C}_{34} \mathrm{H}_{70}$ & n-Tetratriacontane & 9.34 & 478 & 95 \\
\hline 13. & 37.881 & $\mathrm{C}_{44} \mathrm{H}_{90}$ & $\begin{array}{l}\text { n-Tetratetracontane } \\
\text { Oxalic acid, }\end{array}$ & 7.34 & 618 & 94 \\
\hline 14. & 44.044 & $\mathrm{C}_{27} \mathrm{H}_{50} \mathrm{O}_{4}$ & $\begin{array}{c}\text { cyclohexylmethyloctadecyl } \\
\text { ester }\end{array}$ & 0.14 & 438 & 84 \\
\hline
\end{tabular}

Table 2 GC-MS analysis on HSW-16 at $150 \mathrm{mM}$ salt concentration

\begin{tabular}{|c|c|c|c|c|c|c|}
\hline S.No. & Run Time & Formula & Compound & $\%$ Area & $\begin{array}{c}\text { Relative } \\
\text { Molecular } \\
\text { mass }\end{array}$ & $\begin{array}{c}\text { Match } \\
\text { quality } \\
\%\end{array}$ \\
\hline 1. & 9.527 & $\mathrm{C}_{17} \mathrm{H}_{36} \mathrm{O}$ & 1-Heptadecanol & 0.07 & 256 & 95 \\
\hline 2. & 14.756 & $\mathrm{C}_{19} \mathrm{H}_{40} \mathrm{O}$ & 1-Nonadecanol & 0.13 & 284 & 96 \\
\hline 3. & 19.741 & $\mathrm{C}_{24} \mathrm{H}_{50} \mathrm{O}$ & 1-Tetracosanol & 0.14 & 354 & 96 \\
\hline 4. & 26.593 & $\mathrm{C}_{25} \mathrm{H}_{52}$ & N-Triacontane & 1.92 & 352 & 96 \\
\hline 5. & 28.656 & $\mathrm{C}_{24} \mathrm{H}_{50}$ & n-Tetracosane & 4.65 & 338 & 95 \\
\hline 6. & 30.642 & $\mathrm{C}_{40} \mathrm{H}_{82}$ & N-Tetracontane & 8.22 & 562 & 95 \\
\hline 7. & 32.553 & $\mathrm{C}_{36} \mathrm{H}_{74}$ & N-Hexatriacontane & 11.20 & 506 & 95 \\
\hline 8. & 34.386 & $\mathrm{C}_{25} \mathrm{H}_{52}$ & Pentacosane & 12.56 & 352 & 95 \\
\hline 9. & 36.145 & $\mathrm{C}_{34} \mathrm{H}_{70}$ & n-Tetratriacontane & 12.15 & 478 & 95 \\
\hline 10. & 37.831 & $\mathrm{C}_{44} \mathrm{H}_{90}$ & n-Tetratetracontane & 10.25 & 618 & 94 \\
\hline
\end{tabular}

Table 3 GC-MS analysis on HSW-16 at $175 \mathrm{mM}$ salt concentration

\begin{tabular}{lccccc}
\hline S.No. & Run Time & Formula & Compound & $\begin{array}{c}\text { Relative } \\
\text { Area } \\
\text { Molecular } \\
\text { mass }\end{array}$ & $\begin{array}{c}\text { Match } \\
\text { quality } \\
\text { \% }\end{array}$ \\
\hline 1. & 28.631 & $\mathrm{C}_{24} \mathrm{H}_{50}$ & n-Tetracosane & 3.08 & 338 \\
2. & 30.594 & $\mathrm{C}_{40} \mathrm{H}_{82}$ & N-Tetracontane & 6.20 & 562 \\
3. & 32.497 & $\mathrm{C}_{29} \mathrm{H}_{60}$ & N-Nonacosane & 9.58 & 408 \\
4. & 34.322 & $\mathrm{C}_{25} \mathrm{H}_{52}$ & Pentacosane & 10.85 & 352 \\
5. & 36.086 & $\mathrm{C}_{36} \mathrm{H}_{74}$ & N-Hexatriacontane & 11.20 & 506 \\
6. & 37.787 & $\mathrm{C}_{25} \mathrm{H}_{52}$ & N-Triacontane & 10.01 & 35 \\
7. & 39.432 & $\mathrm{C}_{34} \mathrm{H}_{70}$ & n-Tetratriacontane & 6.88 & 95 \\
\hline
\end{tabular}

Table 4 GC-MS analysis on HSW-16 at $200 \mathrm{mM}$ salt concentration

\begin{tabular}{|c|c|c|c|c|c|c|}
\hline S.No. & Run Time & Formula & Compound & $\%$ Area & $\begin{array}{c}\text { Relative } \\
\text { Molecular } \\
\text { mass }\end{array}$ & $\begin{array}{c}\text { Match } \\
\text { quality } \\
\%\end{array}$ \\
\hline 1. & 19.755 & $\mathrm{C}_{21} \mathrm{H}_{44} \mathrm{O}$ & 1-Heneicosanol & 0.97 & 312 & 96 \\
\hline 2. & 24.338 & $\mathrm{C}_{27} \mathrm{H}_{56} \mathrm{O}$ & 1-Heptacosanol & 0.78 & 396 & 97 \\
\hline 3. & 26.617 & $\mathrm{C}_{30} \mathrm{H}_{62}$ & N-Triacontane & 3.71 & 422 & 96 \\
\hline 4. & 28.551 & $\mathrm{C}_{24} \mathrm{H}_{50} \mathrm{O}$ & n-Tetracosanol-1 & 0.51 & 354 & 85 \\
\hline 5. & 28.693 & $\mathrm{C}_{24} \mathrm{H}_{50}$ & Tetracosane & 6.54 & 338 & 95 \\
\hline 6. & 30.681 & $\mathrm{C}_{40} \mathrm{H}_{82}$ & N-Tetracontane & 9.14 & 562 & 95 \\
\hline 7. & 32.586 & $\mathrm{C}_{36} \mathrm{H}_{74}$ & N-Hexatriacontane & 11.02 & 506 & 94 \\
\hline 8. & 34.411 & $\mathrm{C}_{25} \mathrm{H}_{52}$ & Pentacosane & 10.69 & 352 & 95 \\
\hline 9. & 36.159 & $\mathrm{C}_{44} \mathrm{H}_{90}$ & n-Tetratetracontane & 9.65 & 618 & 94 \\
\hline 10. & 36.659 & $\mathrm{C}_{30} \mathrm{H}_{50}$ & Squalene & 0.41 & 410 & 93 \\
\hline 11. & 37.844 & $\mathrm{C}_{44} \mathrm{H}_{90}$ & $\mathrm{n}$-Tetratriacontane & 7.56 & 618 & 94 \\
\hline
\end{tabular}

Acknowledgement: The authors are grateful to Department of Biotechnology, Govt. of India, New-Delhi for their support by providing the fund for carrying out the research work.

\section{REFERENCES}

Oren, A. 2002. Diversity of halophilic microorganisms: Environments, phylogeny, physiology, and applications. Journal of Industrial Microbiology \& Biotechnology, 28, 56-63. http://dx.doi.org/10.1038/sj/jim/7000176

Vreeland, R.H. 1987. Mechanisms of halotolerance in microorganisms. Critical Review in Microbiology, 14, 311-356. http://dx.doi.org/10.3109/10408418709104443

Miller, K.J. 1986. Effects of monovalent and divalent salts on the phospholipid and fatty acid compositions of a halotolerant Planococcus sp. Applied Environment \& Microbiology, 52, 580-582. http://dx.doi.org/0099$\underline{2240 / 86 / 090580-03 \$ 02.00 / 0}$
Mishra, S., Singh, R.P., Raghuvanshi, S., Gupta, S. 2015. Deducing the bioperspective capabilities of Fe (II) oxidizing bacterium isolated from extreme environment. Biochemistry \& Analytical Biochemistry 4, 166. http://dx.doi.org/10.4172/2161-1009.1000166

Joshi A, Seth, G. 2008.Physico-chemical characteristics of ground water of sambhar lake city and its adjoining area, jaipur district, rajasthan, (India). International Journal of Chemical Science, 6, 1793-1799.

Dworkin, M., Foster, J. 1958. Experiments with some microorganisms which utilize ethane and hydrogen. Journal of Bacteriology, 75:592-03. http://dx.doi.org/10.1007/s10658-014-0560-0

Christie, W.W. 2003. Lipid Analysis. $3^{\text {rd }}$ edition The Oily Press, Bridgwater, UK 